This document was prepared in conjunction with work accomplished under Contract No. DE-AC09-96SR18500 with the U. S. Department of Energy.

\title{
DISCLAIMER
}

This report was prepared as an account of work sponsored by an agency of the United States Government. Neither the United States Government nor any agency thereof, nor any of their employees, nor any of their contractors, subcontractors or their employees, makes any warranty, express or implied, or assumes any legal liability or responsibility for the accuracy, completeness, or any third party's use or the results of such use of any information, apparatus, product, or process disclosed, or represents that its use would not infringe privately owned rights. Reference herein to any specific commercial product, process, or service by trade name, trademark, manufacturer, or otherwise, does not necessarily constitute or imply its endorsement, recommendation, or favoring by the United States Government or any agency thereof or its contractors or subcontractors. The views and opinions of authors expressed herein do not necessarily state or reflect those of the United States Government or any agency thereof. 
WSRC-TR-2005-00332

Rev. 0

\section{Plutonium Surveillance Destructive Examination Requirements at Savannah River National Laboratory for K-Area Interim Surveillance (U)}

\section{T.M. Stefek}

Savannah River National Laboratory

Publication Date: September 2005

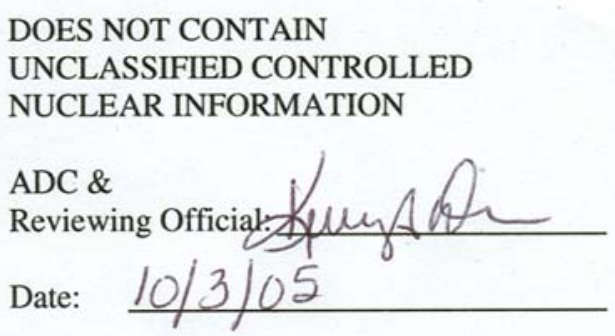

\section{Contributors:}

K.A. Dunn - 3013 Surveillance Program, SRS Program Lead

G.T. Chandler - Pu Surveillance DE Manager

F.A Cheek, D.Z. Nelson - Metallurgical Analysis

R.R Livingston, J.M. Duffey, D.C. Witt - Gas Analysis and Oxide Characterization

A.R. Jurgensen - Chemical Analysis

J.W. McClard - MIS Representative

\section{Westinghouse Savannah River Company}

Savannah River Site

Aiken, SC 29808

This document was prepared in connection with work done under Contract No. DEAC09-89SR18035 with the U. S. Department of Energy 
WSRC-TR-2005-00332

Rev. 0

\section{DISCLAIMER}

This report was prepared as an account of work sponsored by an agency of the United States Government. Neither the United States Government nor any agency thereof, nor any of their employees, makes any warranty, express or implied, or assumes any legal liability or responsibility for the accuracy, completeness, or usefulness of any information, apparatus, product, or process disclosed, or represents that its use would not infringe privately owned rights. Reference herein to any specific commercial product, process, or service by trade name, trademark, manufacturer, or otherwise does not necessarily constitute or imply its endorsement, recommendation, or favoring by the United States Government or any agency thereof. The views and opinions of authors expressed herein do not necessarily state or reflect those of the United States Government or any agency thereof. 
WSRC-TR-2005-00332

Rev. 0

\section{Plutonium Surveillance Destructive Examination Requirements at Savannah River National Laboratory for K-Area Interim Surveillance (U)}

APPROVALS:

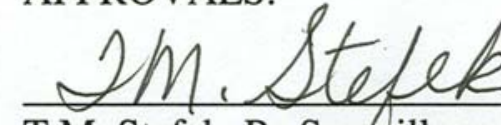

T.M. Stefek, Pu Surgeillance DE Coordinator
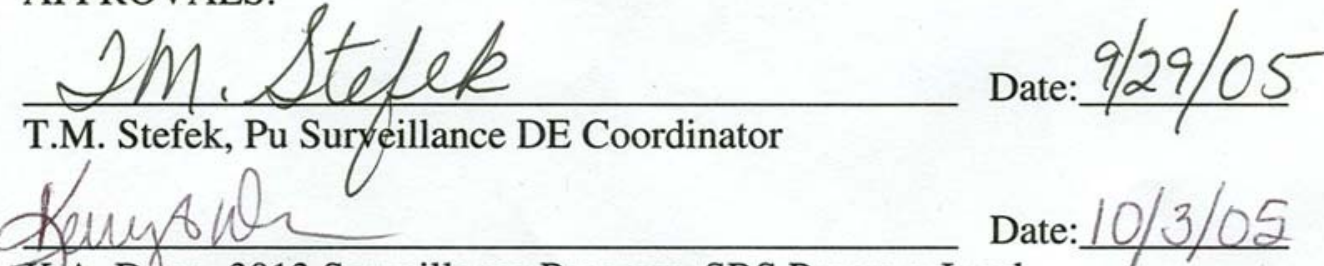

Date: $10 / 3 / 02$

K.A. Dunn, 3013 Surveillance Program, SRS Program Lead

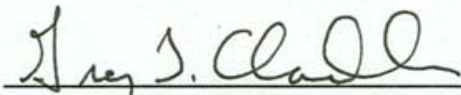

Date: $10 / 3 / 05$

G.T. Chandler, Pu Surveillance DE Manager

Qlice, M. Merray

Date: October 6, 2005

A.M. Murray, Actinide Tegchnology Section Manager

Ar Ctranclen

Date: $10-11-05$

L. M. Chandler, Analytical Development Section Manager

Lat ap s

N.C. Iyer, Materials Technology Section Manager

Cindy Is. Head

Date: $10-17-05$

C.G. Head, SRNL Radiological Controls Manager

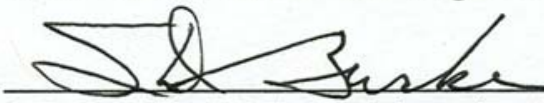

S.D. Burke, NMM Engineering Manager

Date: $10-20-05$

$\rightarrow \omega n: C$

J.W. McClard, MIS Representative

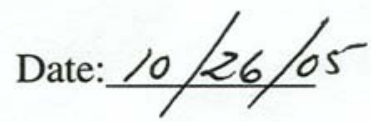

$\angle 2$ tone

Date: $11 / 3 / 05$

L.E. Traver, NMM Engineering

Date: $10 / 26 / 05$ 
WSRC-TR-2005-00332

Rev. 0

\section{Revision Log}

Document No. WSRC-TR-2005-00332 Rev. No. 0

Document Title Plutonium Surveillance Destructive Examination Requirements at Savannah River National Laboratory for K-Area Interim Surveillance

Rev. \# Page \# Description of Revision Date

$0 \quad$ all Original document 9/29/2005 
WSRC-TR-2005-00332

Rev. 0

\section{Table of Contents}

1 INTRODUCTION......................................1

2 ASSUMPTIONS.................................

3 OPERATIONAL CONCEPTS........................2

3.1 Process Flow Logic..............................2

3.2 Normal Operation of Process......................4

3.3 Handling Anomalous Conditions....................6

4 FUNCTIONAL REQUIREMENTS..................6

4.1 Analysis Requirements.........................6

4.1.1 Metallurgical Evaluation...................8

4.1.2 Gas Analysis............................ 8

4.1.3 Pu-bearing Oxide Analysis..................8

4.2 Equipment Requirements.......................9

4.2.1 Metallurgical Evaluation...................9

4.2.2 Gas Analysis............................10

4.2.3 Plutonium Oxide Analysis................10

4.3 Material Accountability Requirements.........11

4.4 Safety and Environmental Requirements .......11

5 COLD TESTING AND DEMONSTRATION.......11

6 REFERENCES...................................12

7 ABBREVIATIONS AND ACRONYMS............12 
WSRC-TR-2005-00332

Rev. 0

\section{INTRODUCTION}

The DOE 3013 storage standard requires nested, welded 300 series stainless steel containers to store plutonium-bearing materials for up to 50 years. ${ }^{1}$ Packaged contents include stabilized plutonium-bearing residues that contain chloride salts and a low (< 0.5 weight \%) water content. The DOE 3013 STD requires surveillance of the packages over the 50 year lifetime. These surveillance requirements have been further defined by the Integrated Surveillance Program ${ }^{2}$ to include both non-destructive examination (NDE) and destructive examination (DE) of the 3013 container. The DE portion of surveillance involves examining the 3013 nested containers, analyzing the head space gas, and evaluating the plutonium oxide chemistry. At SRS, the stored 3013 containers will undergo preparation for the DE surveillance activities in facilities located in K-Area. The actual DE surveillance will be performed in SRNL.

This report provides preliminary functional requirements for the destructive examination (DE) of plutonium-bearing oxide materials and containers in support of KArea Interim Surveillance (KIS). The KIS project will install interim facilities to prepare the samples for analysis in SRNL. This document covers the requirements for the interim period beginning in 2007, and lasting until the Container Storage and Surveillance Capability (CSSC) project provides the permanent facilities in K-Area to perform sampling and repackaging operations associated with the 3013 container storage and surveillance program. Initial requirements for the CSSC project have been previously defined in WSRC-TR-2004-00584 "Plutonium Surveillance Destructive Examination Requirements at Savannah River National Laboratory”. As part of the Plutonium Surveillance Program of 3013 Containers at the Savannah River Site (SRS), the Savannah River National Laboratory (SRNL) will receive the emptied 3013 container components, plutonium oxide samples and headspace gas samples from KArea. The DE program scope includes chemical and metallurgical analyses for a maximum of $25 \mathrm{DE}$ sets a year to provide essential data in support of the SRS Plutonium Surveillance Program. The normal operation is expected to be approximately $15 \mathrm{DE}$ sets a year.

\section{ASSUMPTIONS}

The requirements outlined in this document are based on the following assumptions:

$2.1 \quad$ K-Area Operations will package and ship the set of 3013 container components and samples required for the DE examination to SRNL in a DSF6 package, or approved equivalent.

2.2 Each DE set will include three empty 3013 containers (i.e. outer container, inner container and convenience can) for metallurgical evaluation, up to three headspace gas samples, and up to three plutonium oxide samples. 
WSRC-TR-2005-00332

Rev. 0

2.3 SRNL will have the capacity to perform one DE every two weeks and can complete up to 25 DE's per year. However, the normal operation is expected to be approximately $15 \mathrm{DE}$ sets a year.

2.4 Only routine metallographic and chemical measurements described in this document are included in the SRNL baseline DE scope and schedule. Identification of conditions outside the expected range for the 3013 container or contents require additional review based on observed anomalous conditions to determine what additional analyses are necessary.

2.5 Plutonium oxide sample residues including both liquids and powders will be consolidated and sent to HB-Line. Characterization or additional processing of materials to HB-Line receipt criteria is new scope and will be defined in subsequent documents.

2.6 The metal waste from 3013 containers (e.g., surface contaminated stainless steel samples) will be disposed of by SRNL.

2.7 Metallurgical samples will be archived in SRNL facilities.

2.8 Pu-oxide samples will be archived in either SRNL facilities or in the KArea Complex.

\section{OPERATIONAL CONCEPTS}

The following operational concepts give narrative descriptions of the expected process for the metallurgical evaluation of the 3013 containers, gas analysis, and plutonium oxide analysis. These concepts provide the rationale for the system design requirements that are presented in the next section. Materials Science and Technology (MST) in SRNL will coordinate activities for the DE program. Other SRNL organizations which are contributors to the success of the DE program include the Actinide Technology Section (ATS), Analytical Development Section (ADS) and Laboratory Services Department (LSD). The current division of responsibilities for DE testing is identified in Table 1.

Table 1. SRNL Section Responsibilities for DE Components.

\begin{tabular}{|l|l|}
\hline \multicolumn{1}{|c|}{ DE Components } & \multicolumn{1}{c|}{ Section } \\
\hline Program Coordination & MST \\
\hline Sample Management / Shipping & MST / ATS \\
\hline Visual Examination & MST \\
\hline Metallography & MST \\
\hline Gas Analysis & ATS \\
\hline Moisture Content & ATS / ADS \\
\hline Flowsheet R\&D & ATS \\
\hline Chemical Analysis & ATS / ADS \\
\hline Infrastructure Support & LSD \\
\hline
\end{tabular}


WSRC-TR-2005-00332

Rev. 0

3.1 The following figure provides a process flow logic for samples received by SRNL.

Figure 1 Process Flow Sheet for DE of 3013 Container Metal Components, Headspace Gas, and Pu-Oxide Content

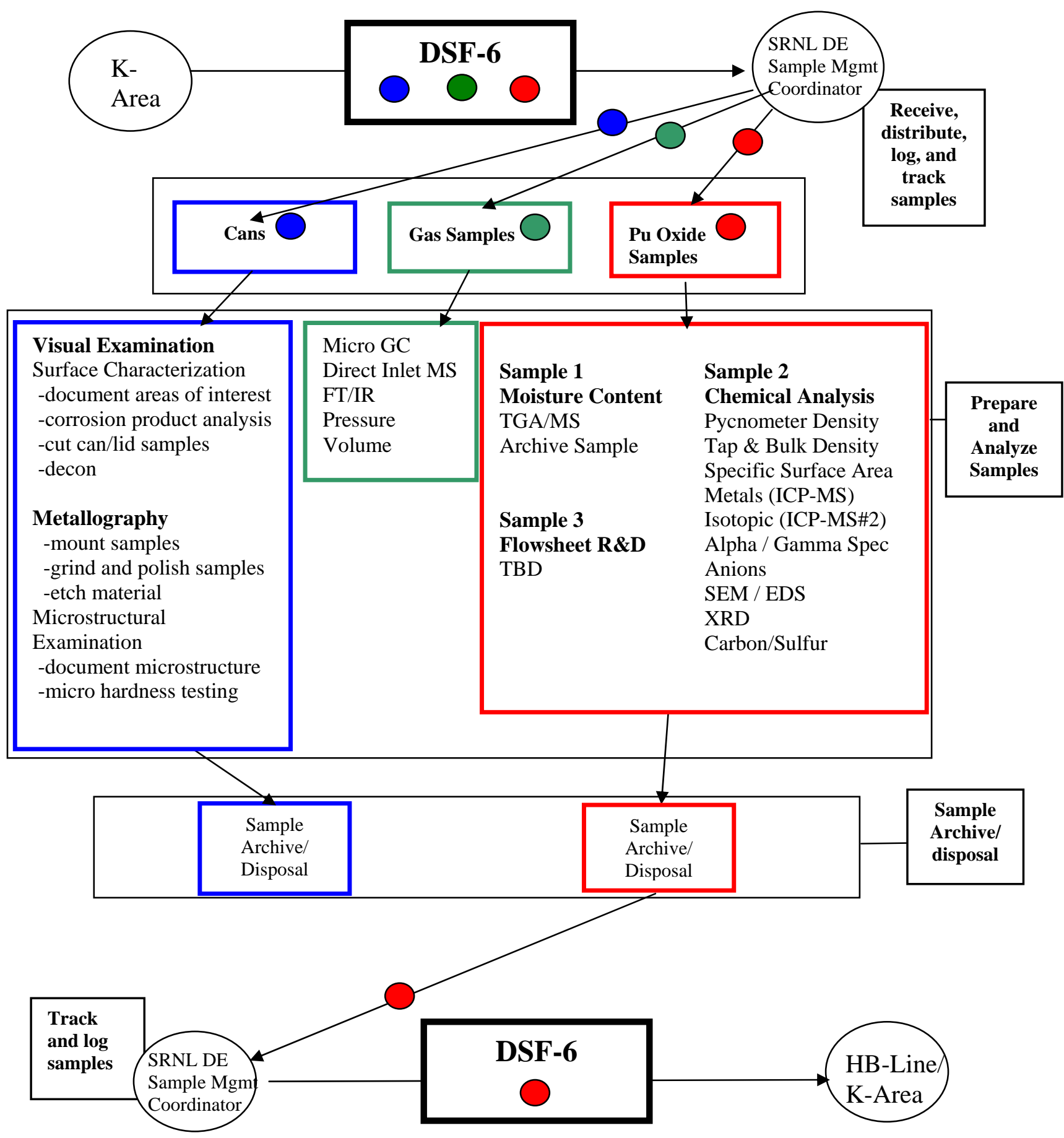


WSRC-TR-2005-00332

Rev. 0

\subsection{Normal Operation of Process}

K-Area Operations personnel will cut the lids off the outer and inner cans, and open the convenience can. All cuts should be made at least $1 / 2$ inch away from any closure weld, fabrication weld, and any heat affected zone (HAZ). K-Area Operations will perform light decontamination of containers to remove any residual plutonium-bearing oxide material. Light decontamination includes such things as tapping the container or brushing the container with a soft bristled brush. Light decontamination does not include wiping the containers with a cloth or using chemical agents to aid in removing residual material from the container. In fact, such activities are prohibited. The convenience can along with the inner and outer 3013 container components will be sent to SRNL for metallurgical evaluation. The initial evaluation will be conducted in a glove box and will consist of a visual examination, surface characterization, and documentation of areas of interest. Corrosion product and pitting may be analyzed; one technique available is Scanning Electron Microscopy (SEM) /Energy Dispersive System (EDS). The samples for routine analysis will be cut, decontaminated, and mounted prior to removal from the glove box. Samples will be metallographically prepared by grinding, polishing, and etching the samples for microstructural examination. A hardness test will be performed on a representative number of samples. The metallographic samples will be archived for a duration to be determined. Remnant container material will be discarded via the SRNL waste system.

K-Area Operations will be responsible for capturing a gas sample from between the outer and inner can, from between the inner and convenience can, and if possible from within the convenience can, by utilizing the can puncture device. Some convenience can designs are expected to allow gas to move between convenience can and the inner 3013 container. However, an attempt to collect a gas sample from each space may still provide additional information on the movement of various gases. Gas samples will be analyzed using a contained Micro Gas Chromatograph (GC), Direct Inlet Mass Spectrometer (MS), and Fourier Transform - Infrared Spectrophotometer (FTIR). The pressure and volume of the sample will be measured by SRNL in order to back calculate moles of gas generated. The sample containers will be monitored by SRNL prior to use to assure cleanliness and proper evacuation. The protocol for sample container preparation and implementation with the can puncture device will be incorporated in K-Area procedures, as required. 
Rev. 0

Three separate and representative samples of plutonium oxide, two containing approximately 20 grams, and one containing approximately 30 grams, will be packaged in K-area for transfer to SRNL for analysis. The first sample consists of an $8 \mathrm{~mL}$ stainless steel B-vial with o-ring seal filled approximately $80 \%$ full with a powder sample. This sample will be analyzed in a glove box using Thermo-Gravimetric Analyzer (TGA) MS to determine loss on ignition (LOI) and moisture content. The stainless steel vials will be pre-weighed to the nearest 0.1 gram before sampling to allow determination of the sample mass after sealing and tracking any changes in sample due to adsorption or desorption of moisture after sealing. The mass of this sample is expected to be somewhere around 20grams of bulk, depending on sample density. This sample is packaged separately to ensure the moisture content is preserved during handling. The size of this sample allows for duplicate TGA measurements when required and the remaining unused sample and stainless steel vial will be used for the archive sample.

The second sample of Pu-bearing oxide (20 grams) will be split into four parts and prepared, as required, for various analytical measurements. The first part will be analyzed using the pycnometer to determine the sample's crystal density. The second part will be used for bulk and tap density measurements then subsequently evaluated for specific surface area using the Brunauer Emmet Teller (BET) method. The second part will be characterized using the SEM/EDS and X-Ray Diffraction (XRD) to determine powder morphology, elemental analysis by $\mathrm{x}$-ray fluorescence (XRF) and composition of the crystaline oxides by XRD. The third part will be dissolved and submitted to ADS for Inductively Coupled Plasma Emission Spectroscopy (ICP/ES), ICPMS, Radchem, and Ion Chromatography. This analysis may require multiple dissolution techniques to gain somewhat complete digestion of the sample and allow for compatibility with the analytical methods recommended. The fourth part will be used for carbon sulfur analysis by ignition of the sample in LECO analyzer and quantitative infrared measurement of a carrier gas for $\mathrm{CO}_{2}$ and $\mathrm{SO}_{2}$ composition. Excess plutonium materials, both solid and liquid, will be packaged and sent to HB-Line recovery. It is assumed that this activity will require minimal preparation of the materials prior to shipping and the existing safety basis for the DSF-6 is sufficient for this activity.

The third sample of material (approximately 30 grams) will be used for flowsheet analysis. This scope is new for the SRNL DE program and additional details are required to be worked out separately between SRNL and H-Area to determine flowsheet test requirements and to more precisely define sample size. Key information includes baseline flowsheet conditions, analytical requirements, and identification of adequate glove box capability in SRNL. The dissolution of larger quantities of potentially high chloride-bearing oxides may present some new challenges for the SRNL facility infrastructure. 
WSRC-TR-2005-00332

Rev. 0

SRNL operating procedures will be used to conduct the DE, as prescribed by the surveillance program. The data collected will be entered in a DE Field Surveillance Module (FSM) for the ISP (Integrated Surveillance Program) Database. SRNL will have the capacity to perform one DE every two weeks and can complete up to 25 DE's per year. However the normal operation is expected to be approximately $15 \mathrm{DE}$ sets a year.

The cut 3013 containers, gas samples, and plutonium oxide samples will be individually packaged for transportation to SRNL in a DSF-6 package, or an approved equivalent. These items constitute one DE set. Transportation of the DE set will be coordinated between K-Area and the SRNL DE Sample Management Coordinator (SMC). The DE set will be received, logged, distributed and tracked by the SMC.

\subsection{Handling Anomalous Conditions}

Anomalous conditions identified during the evaluation (e.g., unexpected gas composition or extensive corrosion of a containment layer) will be reviewed on a case by case basis. If it is determined that the conditions warrant further evaluation, additional analytical and metallographic measurements may be performed to provide insight into the observed conditions. These measurements and subsequent evaluation are beyond the established baseline for this program.

\section{FUNCTIONAL REQUIREMENTS}

This section provides the requirements for the test analyses, equipment needs, nuclear material accountability, safety and environmental concerns, and facility interface requirements. These requirements are grouped into major functional categories and split into sections for each type of analysis: 1) container metallurgy 2) headspace gas composition, and 3) Pu-bearing oxide properties. Detailed information will be presented in other documents to support these functional requirements.

\subsection{Analysis Requirements}

This table displays the analysis requirements for the DE of the 3013 containers, gas analyses and plutonium-bearing oxide analyses. SRNL and Materials Identification and Surveillance (MIS) representatives developed these requirements based on the ISP and the Surveillance and Monitoring (S\&M) Plan. Equipment expected to be used for these analyses is listed in section 4.2. 
WSRC-TR-2005-00332

Rev. 0

Table 2 Analysis Requirements

\begin{tabular}{|c|c|c|c|}
\hline EVALUATION & $\frac{\text { ISP EXAMPLES }}{\text { [ref.1] }}$ & $\frac{\text { S\&M PLAN }}{\text { [ref.2] }}$ & $\frac{\text { TECHNICAL }}{\text { REQUIREMENTS }}$ \\
\hline Pressure & $\begin{array}{l}\text { Pressure measurement } \\
\text { in puncture device }\end{array}$ & $\begin{array}{l}\text { Pressure } \\
\text { measurement in } \\
\text { puncture device }\end{array}$ & $\begin{array}{l}\text { Pressure instrument } \\
\text { calibrated to measure } \\
0-700 \text { psig }\end{array}$ \\
\hline Gas Analysis & MS or Raman & GC and $\mathrm{MS}$ & $\begin{array}{l}\text { Identify species causing } \\
\text { pressure buildup and } \\
\text { possible corrosive } \\
\text { species. At a minimum, } \\
\text { measurement of } \mathrm{H}_{2}, \mathrm{O}_{2} \text {, } \\
\mathrm{N}_{2}, \mathrm{H}_{2} \mathrm{O}, \mathrm{He}, \mathrm{HCl}, \mathrm{HF} \text {, } \\
\mathrm{CO}, \mathrm{CO}_{2}, \mathrm{NO}_{\mathrm{x}}, \mathrm{SO}_{\mathrm{x}}, \mathrm{CH}_{\mathrm{x}}\end{array}$ \\
\hline $\begin{array}{l}\text { Moisture Content of } \\
\text { Material }\end{array}$ & Approved method & Unspecified & TGA-MS \\
\hline $\begin{array}{l}\text { Chemical } \\
\text { Composition of } \\
\text { Material }\end{array}$ & $\begin{array}{l}\text { Actinide assay, } \\
\text { ICP/ES, ICP/MS, } \\
\text { XRF, LIBS, Cl, S, F, } \\
\text { etc. }\end{array}$ & Unspecified & $\begin{array}{l}\text { Impurity analyses to } \\
\text { interpret gas and } \\
\text { corrosion analyses. } \\
\text { At a minimum, } \\
\text { measurement of metal } \\
\text { impurities, Cl, F, S, C. } \\
\text { Also ability to identify } \\
\text { corrosion/gas generating } \\
\text { compounds }\end{array}$ \\
\hline $\begin{array}{l}\text { Physical } \\
\text { Characteristics of } \\
\text { Material }\end{array}$ & $\begin{array}{l}\text { Visual, image } \\
\text { documentation, } \\
\text { density, particle size, } \\
\text { surface area }\end{array}$ & $\begin{array}{l}\text { Visual, image } \\
\text { documentation, } \\
\text { density, particle } \\
\text { size, surface area }\end{array}$ & $\begin{array}{l}\text { General characterization } \\
\text { to interpret other results }\end{array}$ \\
\hline $\begin{array}{l}\text { Container/Content } \\
\text { Interaction }\end{array}$ & $\begin{array}{l}\text { Visual, image } \\
\text { documentation, } \\
\text { metallography, } \\
\text { SEM/EDS }\end{array}$ & $\begin{array}{l}\text { Visual, } \\
\text { metallography, } \\
\text { SEM, EDS }\end{array}$ & $\begin{array}{l}\text { Evaluate for indications } \\
\text { of corrosion/ degradation } \\
\text { of containers. }\end{array}$ \\
\hline
\end{tabular}


WSRC-TR-2005-00332

Rev. 0

\subsubsection{Metallurgical Evaluation}

A metallurgical evaluation of the 3013 container is required to identify whether any degradation of the container, such as pitting corrosion or stress corrosion cracking, is occurring. This metallurgical evaluation will examine the interaction between the plutonium contents and the containers. The outer can, inner can, and convenience can from each 3013 package chosen for destructive surveillance activities will be provided to SRNL for metallurgical analyses. Each container will be visually examined. When present in sufficient quantity, the corrosion product(s) will be analyzed to assist in determining the corrosive species and mechanism. Approximately eight metallographic samples will be sectioned from each container, with a focus on high stress regions and areas with corrosion product or degradation.

\subsubsection{Gas Analysis}

The 3013 package selected for DE as part of the plutonium surveillance program will be punctured in order to capture the gases present within each void volume. The outer can will be punctured first and a gas sample will be captured. A gas sample will be taken from between the inner can and the convenience can, and possibly from within the convenience can. The pressure of each void volume will be measured and each gas sample will be transferred to SRNL. The gas samples will be analyzed to identify the different species present and measure the major components. Sample container volume and associated pressure limits will be established with K-area Operations in a future document to support implementation of SRNL flammable gas limits for glove box operations. Techniques capable of detecting and measuring trace quantities of the following headspace gas species have been selected: $\mathrm{H}_{2}, \mathrm{O}_{2}, \mathrm{~N}_{2}, \mathrm{H}_{2} \mathrm{O}$, $\mathrm{He}, \mathrm{HCl}, \mathrm{HF}, \mathrm{CO}, \mathrm{CO}_{2}, \mathrm{NO}_{\mathrm{x}}, \mathrm{SO}_{\mathrm{x}}, \mathrm{CH}_{\mathrm{x}}$.

\subsubsection{Pu-bearing Oxide Analysis}

Representative samples of the Pu-bearing oxide material will be taken from the 3013 container chosen for DE and will be subjected to moisture analysis, chemical analyses and physical property measurements, and flowsheet analysis. The accepted methods for moisture analysis within the DOE complex are TGA/MS and TGA/ IR. 
WSRC-TR-2005-00332

Rev. 0

Physical characteristics of the Pu-bearing oxide, such as density, particle size, and surface area must be obtained and documented along with a visual inspection of the material. These measurements will support a comparison of material characteristics with other samples.

A chemical composition analysis of the Pu-bearing oxide shall be performed to identify the impurities within the material in order to aid in the interpretation of the gas and corrosion analyses results. At a minimum, a measurement of elemental impurities such as $\mathrm{Cl}, \mathrm{F}, \mathrm{S}$, and $\mathrm{C}$ is required. The identification of corrosion/gas generating compounds is expected to provide important data for surveillance program management.

\subsection{Equipment Requirements}

The following section consists of tables describing the expected equipment needs for the DE of the 3013 containers, gas analyses and plutonium-bearing oxide analyses. The equipment needs were developed based on the analysis requirements presented in the previous section. The locations listed in Table $3-$ 5 are currently the preferred locations for equipment and analyses. Details regarding cost estimates and scheduling of modifications to the labs and equipment will be provided in a separate document.

\subsubsection{Metallurgical Evaluation Equipment Requirements}

Table 3. Metallurgical Evaluation Equipment Requirements

\begin{tabular}{|l|l|l|l|}
\hline \multicolumn{1}{|c|}{ Location } & \multicolumn{1}{|c|}{ Equipment } & \multicolumn{1}{|c|}{ Purpose } & $\begin{array}{l}\text { Purchasel } \\
\text { Exists }\end{array}$ \\
\hline SRNL, C-059 & Microscope & Visual characterization of containers & $\begin{array}{l}\text { Order } \\
\text { Placed }\end{array}$ \\
\hline SRNL, C-059 & Saw & Cut container specimens & $\begin{array}{l}\text { Order } \\
\text { Placed }\end{array}$ \\
\hline SRNL, C-059 & Camera & $\begin{array}{l}\text { Documentation of visual } \\
\text { characterization }\end{array}$ & Purchase \\
\hline SRNL, C-059 & Ultrasonic Cleaner & Metallography - sample preparation & Exists \\
\hline SRNL, C-059 & Mounting Equipment & Metallography - sample preparation & Exists \\
\hline SRNL, C-126 & $\begin{array}{l}\text { Automatic } \\
\text { Grinder/Polisher }\end{array}$ & Metallography - sample preparation & Exists \\
\hline SRNL, C-126 & Etcher/Power Supply & Metallography - sample preparation & Exists \\
\hline SRNL, C-126 & Metallograph & $\begin{array}{l}\text { Microstructural } \\
\text { evaluation/documentation }\end{array}$ & $\begin{array}{l}\text { Order } \\
\text { Placed }\end{array}$ \\
\hline SRNL, C-126 & Microhardness Tester & Microstructural evaluation & Exists \\
\hline
\end{tabular}


WSRC-TR-2005-00332

Rev. 0

\subsubsection{Gas Analysis Equipment Requirements}

Table 4. Gas Analysis Equipment Requirements

\begin{tabular}{|l|l|l|l|}
\hline \multicolumn{1}{|c|}{ Location } & \multicolumn{1}{|c|}{ Equipment } & \multicolumn{1}{|c|}{ Purpose } & \multicolumn{1}{c|}{$\begin{array}{c}\text { Purchasel } \\
\text { Exists }\end{array}$} \\
\hline SRNL, B-135/139 & $\begin{array}{l}\text { Micro Gas } \\
\text { Chromatograph }\end{array}$ & $\mathrm{H}_{2}, \mathrm{~N}_{2}, \mathrm{O}_{2}, \mathrm{CO}, \mathrm{CO}_{2}, \mathrm{CH}_{4}$ & Exists \\
\hline SRNL, B-135/139 & Direct Inlet Mass Spec & $\mathrm{CH}_{x}, \mathrm{CH}_{x} \mathrm{O}_{\mathrm{CH}_{\mathrm{x}} \mathrm{N}}$ & Exists \\
\hline SRNL, B-135/139 & FT/IR & $\mathrm{HF}, \mathrm{HCl}, \mathrm{NO}_{x}, \mathrm{SO}_{\mathrm{x}}$ & Purchase \\
\hline
\end{tabular}

\subsubsection{Pu-bearing Oxide Analysis Equipment Requirements}

Table 5. Plutonium Oxide Analysis Equipment Requirements

\begin{tabular}{|c|c|c|c|}
\hline Location & Equipment & Purpose & $\begin{array}{l}\text { Purchasel } \\
\text { Exists }\end{array}$ \\
\hline SRNL, B-135/139 & Camera & Pu Oxide characterization (homogeneity) & Purchase \\
\hline SRNL, B-135/139 & Balance & Pu Oxide sample prep and dissolution & Purchase \\
\hline SRNL, B-135/139 & Furnace/Hot Plate & Dissolution for chemical analysis & Purchase \\
\hline SRNL, C-154/158 & TGA/MS & $\begin{array}{l}\text { Moisture content, adsorbed species, } \\
\text { validate stabilization }\end{array}$ & Exists \\
\hline SRNL, C-154/158 & BET & Specific Surface Area & Exists \\
\hline SRNL, C-154/158 & Pycnometer & $\begin{array}{l}\text { Crystal Density (needed to calculate free } \\
\text { volume in 3013) }\end{array}$ & Purchase \\
\hline SRNL, C-154/158 & Bulk/Tap Density & $\begin{array}{l}\text { Pu Oxide characterization (validate } 3013 \\
\text { assumptions) }\end{array}$ & Purchase \\
\hline $\begin{array}{l}\text { SRNL, B-147 } \\
\text { B-067 }\end{array}$ & $\begin{array}{l}\text { ICP/MS and } \\
\text { ICP/ES }\end{array}$ & $\begin{array}{l}\text { Isotopic measurements, Impurities } \\
\text { analysis }\end{array}$ & Exists \\
\hline SRNL, B-142 & Rad chem & $\begin{array}{l}\text { Specific heat calculation, Rad material } \\
\text { composition }\end{array}$ & Exists \\
\hline SRNL, B-134 & Ion Chromatograph & Anion quantitation (e.g. $\mathrm{Cl}, \mathrm{SO}_{4}$ ) & Exists \\
\hline SRNL, B-135/139 & $\begin{array}{l}\text { Carbon/ Sulfur } \\
\text { Analyzer }\end{array}$ & Carbon / Sulfur Analysis & Purchase \\
\hline SRNL, C-134 & SEM/EDS & $\begin{array}{l}\text { Particle size, elemental analysis, sample } \\
\text { morphology }\end{array}$ & Exists \\
\hline SRNL, C-119 & XRD & $\begin{array}{l}\text { Identification of major components (e.g. } \\
\mathrm{PuO}_{2}, \mathrm{U}_{\mathrm{x}} \mathrm{O}_{\mathrm{y}}, \mathrm{PuCl}_{3}, \mathrm{MgO}, \mathrm{KMgCl}_{3} \text { etc) }\end{array}$ & Exists \\
\hline
\end{tabular}


WSRC-TR-2005-00332

Rev. 0

\subsection{Material Accountability Requirements}

A cross-divisional task team has been established and is working to ensure that material accountability requirements are properly dispositioned. Material transfers, movement from K-Area to SRNL, within SRNL, and returns to HBLine and K-Area are being addressed. An accountability system will be used to track accountable nuclear material throughout the process. DE shipments to SRNL and sample returns to HB-Line and/or K-Area will be coordinated by the SRNL DE SMC. Detailed information will be presented in future documents to define the material accountability requirements.

\subsection{Safety and Environmental Requirements}

The process for the DE of the 3013 containers shall include operating practices and/or administrative controls designed to ensure effective radiological control practices in accordance with the appropriate site and regulatory requirements.

A detailed safety evaluation addressing the hazards associated with SRNL activities required for $3013 \mathrm{DE}$ will be presented in the Conduct of Research and Development Hazard Assessment document, which will include the controls required for handling beryllium. This document will serve as the umbrella for the safety evaluation of $\mathrm{DE}$ activities and will include consideration of the following: Job Hazards Analysis (JHA), Radiological Safety, Unreviewed Safety Question (USQ) Determination, Fire Protection, Industrial Hygiene and Chemical Hazards, Environmental Conditions and Compliance, and Waste Management.

\section{COLD TESTING AND DEMONSTRATION}

A task and quality assurance plan will be developed to detail how SRNL will perform non-radioactive testing. This task plan will use simulated containers and contents to support a demonstration of the SRNL facility and equipment capabilities for routine examination of 3013 containers, gas and Pu-bearing oxide samples. 
WSRC-TR-2005-00332

Rev. 0

\section{REFERENCES}

[1] Surveillance and Monitoring Plan for DOE-STD-3013 Materials (U), SR-NMPD03-001, Rev 0.

[2] Integrated Surveillance Program in Support of Long-Term Storage of PlutoniumBearing Materials, LA-UR-00-3246 Rev. 1, Los Alamos National Laboratory

[3] WSRC-TR-2004-00584, Plutonium Surveillance Destructive Examination Requirements at Savannah River National Laboratory, November 2004

\section{ABBREVIATIONS AND ACRONYMS}

$\begin{array}{ll}\text { ADS } & \text { Analytical Development Section } \\ \text { ATS } & \text { Actinide Technology Section } \\ \text { BET } & \text { Brunauer Emmet Teller analysis } \\ \text { CSSC } & \text { Container Storage and Surveillance Capability } \\ \text { DE } & \text { Destructive examination } \\ \text { FSM } & \text { Field Surveillance Module } \\ \text { FT/IR } & \text { Fourier Transform - Infrared Spectrophotometer } \\ \text { GC } & \text { Gas Chromatograph } \\ \text { HAZ } & \text { Heat Affected Zone } \\ \text { ICP/ES } & \text { Inductively Coupled Plasma Emission Spectroscopy } \\ \text { ISP } & \text { Integrated Surveillance Program } \\ \text { KAMS } & \text { K-Area Material Storage } \\ \text { KIS } & \text { K-Area Interim Surveillance } \\ \text { LIBS } & \text { Laser-Induced Breakdown Spectrometer } \\ \text { LOI } & \text { Loss on Ignition } \\ \text { MS } & \text { Mass Spectrometer } \\ \text { MIS } & \text { Materials Identification and Surveillance } \\ \text { MTD } & \text { Measurement Technology Department } \\ \text { MST } & \text { Materials Science and Technology } \\ \text { NMM } & \text { Nuclear Materials Management } \\ \text { R \& D } & \text { Research and Development } \\ \text { RCO } & \text { Radiological Control Operations } \\ \text { S\&M } & \text { Surveillance and Monitoring } \\ \text { SEM/EDS } & \text { Scanning Electron Microscope/Energy Dispersive System } \\ \text { SMC } & \text { Sample Management Coordinator } \\ \text { SMTD } & \text { Strategic Materials \& Technology Department } \\ \text { SRNL } & \text { Savannah River National Laboratory } \\ \text { TGA } & \text { Thermo-Gravimetric Analyzer } \\ \text { TRU Waste } & \text { Transuranic Waste } \\ \text { XRD } & \text { X-Ray Diffraction System } \\ \text { XRF } & \text { X-Ray Fluorescence } \\ & \\ & \end{array}$


WSRC-TR-2005-00332

Rev. 0

CC:

D.M. Barnes, 705-K

S.D. Burke, 705-K

G.T. Chandler, 773-A

L.M. Chandler, 773-A

F.A. Cheek, 773-A

K.A. Dunn, 773-41A

K.J. Durrwachter, 705-K

C.G. Head, 773-A

N.C. Iyer, 773-41A

A.R. Jurgensen, 773-A

R.R. Livingston, 773-A

J.W. McClard, 703-H

D.Z. Nelson, 773-A

R.J. Martini, 704-9K

A.M. Murray, 773-A

J.B. Schaade, 704-2H

B.R. Seward, 705-K

F.D. Sinclair, 707-C

R.M. Sprague, 705-K

T.M. Stefek, 773-41A

L.E. Traver, 705-K

D.C. Witt, 773-A

Records Management 